\title{
DO IPO HOT AND COLD MARKETS EXIST AT THE INDONESIA STOCK EXCHANGE?
}

\author{
Doni S. Warganegara ${ }^{1}$; Dezie L. Warganegara ${ }^{2}$ \\ ${ }^{1}$ Accounting Department, Universitas Lampung \\ ${ }^{2}$ Accounting Department, Faculty of Economic and Communication, BINUS University \\ Jln. K.H. Syahdan No 9, Palmerah, Jakarta Barat 11480 \\ dezie@binus.edu
}

\begin{abstract}
This study focuses on IPO Initial Returns in Hot and Cold IPO Markets at the Indonesia Stock Exchange (IDX) between the period of 2001 and 2005. This study uses a regression analysis where the first day IPO stock return is the dependent variable and a dummy variable that represents Hot and Cold IPO Markets is the main independent variabel. It is found that Hot and Cold Markets do exist at the IDX. More importantly, it is found that the difference in IPO Initial Returns between Hot and Cold Markets while controlling for other factors is 36.8\%. The Investment Sentiment Hypothesis has been found to explain the existence of Hot and Cold Markets. The hypothesis implies that jumps in IPO Initial Returns during Hot Markets are due to the increase in the first day closing prices which are higher than the increase in the offering prices. The Monopsony Power Hypothesis and information spillovers across IPOs respectively may also provide alternative explanations to the phenomenon. Investment banker community in a small economy learns information from each other and, thus, has full information on the number of firms that will go public in the following period. Consequently, investment bankers have a high bargaining power of investment bankers in lowering the offering prices.
\end{abstract}

Keywords: IPO, initial returns, hot IPO Market, cold IPO Market, Indonesia stock exchange

\begin{abstract}
ABSTRAK
Penelitian ini fokus pada besaran imbal hasil awal pada penawaran saham perdana (IPO) saat banyak jumlah perusahaan melakukan IPO (Hot IPO Market) dan pada saat sedikit jumlah perusahaan melakukan IPO (Cold IPO Market). Penelitian menggunakan analisis regresi yang mana imbal hasil hari pertama suatu saham perdana sebagai variabel bebas dan suatu variabel dummy yang mewakili Hot dan Cold IPO Markets sebagai variabel tidak bebas. Penelitian menemukan bahwa pada Bursa Effek Indonesia periode 2001 hingga 2005 terjadi perbedaan imbal hasil perdana antara Hot Market dan Cold Market. Besaran imbal hasil awal setelah mempertimbangkan variabel pengendali adalah 36,8\%. Penyebab fenomena ini dapat diterangkan pada hipotesis sentimen investasi yang mana besarnya imbal hasil perdana pada Hot Market sentimen investor sangat tinggi sehingga menyebabkan harga penutupan pada hari pertama melonjak jauh dibandingkan dengan harga penawaran perdananya. Di samping hipotesis sentimen investasi, penjelasan tentang hipotesis kekuatan monopsoni dan tentang bocornya informasi dapat juga menjadi acuan dalam menjelaskan fenomena ini. Bankir Investasi saling memberikan informasi sehingga mereka mempunyai informasi yang lebih lengkap sehingga memiliki daya tawar lebih tinggi untuk menekan harga perdana dibandingkan dengan perusahaan dalam proses penentuan harga saham perdana.
\end{abstract}

Kata kunci: IPO, initial returns, hot IPO Market, cold IPO Market, Bursa Efek Indonesia 


\section{INTRODUCTION}

The pricing of IPOs has attracted the academic communities as early as 1960s. Among the first studies in the subject is the one conducted by Reilly and Hatfield (1969). They find that investors in new stocks gain short-run abnormal returns ranging between 1 percent and 95 percent. Using more sophisticated statistical techniques, Ibbotson (1975) confirms the findings regarding the initial performance of IPO stocks and argues that the source of these abnormal returns is not the aftermarket inefficiency but rather due to downward biases in offering prices of new issues. Since then, researchers in the field have advanced models and test hypotheses to reveal these perplexing phenomena (Butler, Keefe, and Kieschnick, 2014).

This study uses IPO data from the Indonesia Stock Exchange (IDX) between the period of 2001 and 2005 to investigate the IPO Initial Returns and factors correlate with them. It is found that Hot and Cold Markets exist in Indonesian stock market. The difference in IPO Initial Returns between Hot and Cold Markets while controlling for other factors is 36.8\%. Lowry (2003) and Helwege and Liang (2004) note that the Investment Sentiment Hypothesis has been found to explain the existence of Hot and Cold Markets and the differential in Initial Returns during those two IPO market characteristics. With regard to higher IPO Initial Returns in the Hot Markets, the Investment Sentiment Hypothesis predicts that the first day closing prices and the offering prices during Hot Markets are higher than Cold Markets. To have jumps in IPO Initial Returns during Hot Markets, therefore, the increase in the first day closing prices must be higher than in the offering prices.

This study also discusses the possibility that during Hot Markets, the first day closing prices increase while the offering prices decrease. The Monopsony Power Hypothesis as advanced by Ritter (1984) is used to explain the phenomenon. The Indonesia Stock Exchange is a small equity market and Indonesia is a small economy. In a small community, the investment banker community has a very good idea about the numbers of firms that will go public in the following period. Armed with this information and given that investment bankers take institutional investors' side, they will drive hard bargain to lower offering prices on behalf of those influential clients. As a result, in the Hot Markets, first day closing prices are higher due to a wild bullishness of investors and offering prices are lower due to a high bargaining power of investment bankers.

The Monopsony Power Hypothesis and information spillovers across IPOs as advanced by Ritter (1984) and Alti (2005) respectively may also provide alternative explanations to the phenomenon. Investment banker community in a small economy learns information from each other and, thus, has full information on the number of firms that will go public in the following period. Consequently, investment bankers have a high bargaining power of investment bankers in lowering the offering prices.

The remainder of this paper is organized as follows. Section two contains the literature review on IPO Initial Returns and their relationship with IPO Volumes. Section three discusses the data. Section four reports the empirical results using both univariate and multivariate analyses. The last section offers final conclusions on this study.

\section{Literature Review}

IPO Initial Returns

The most cited explanations to the huge IPO Initial Return phenomenon are the ones that based on asymmetric information among participants in the IPO market; the issuer, the underwriter(s), and the investors. Rock (1986) and Ritter (1984) contended that there were two kinds of investors, 
completely informed and completely uninformed regarding the desirability of the shares being sold. Since the number of shares subscribed often far exceeds the number of shares available, uninformed investors face a potential "winner's curse". This means that they are only allocated by a sufficient number of shares in less desirable IPOs and by less than sufficient number of shares in more desirable IPOs. Uninformed investors get all of the shares they demand simply because informed investors do not want the shares. Facing with this systematic bias in the allocation of new issues, uninformed investors will only participate in the IPO market if new issues are sufficiently underpriced. Accordingly, the greater the uncertainty regarding the desirability of new issues, the bigger the amount of underpricing demanded by the investors.

The existence of information asymmetry among investors may also lead to information cascade as in Welch (1992), Loughran and Ritter (2001), and Daniel (2001). Potential investors do not only use their own information to purchase new issue, they also pay attention to other investors' actions. Investors, based on their private information, may find some new issues to be desirable, but if they see no one buys the issues, they may cancel their purchases. To set off a cascading process, where all subsequent investors purchase new issues regardless of their private information, an issuer has to underprice an issue to induce the first few potential investors to buy.

Information asymmetry arguments also have been used to explain a partial adjustment of the offer price to new information (Benveniste and Spindt, 1989; Loughran and Ritter, 2002). Given that issuers want to get the full advantage of their ability to raise capital and underwriters want to maximize their underwriting spread, if there is strong demand, new issues will be set at higher offer prices. But if potential investors know that showing a willingness to pay a high price will result in a higher offer price, these investors must be offered something in return. Investment bankers compensate those investors in the form of underpricing that is resulted from the partial price adjustment instead of full adjustment. Because of this partial adjustment, IPOs of which the offer price is revised upwards will be more underpriced than those of which the offer price is revised downwards.

The aforementioned asymmetric information arguments are far from complete in explaining the underpricing of new issues. They only address the necessity to be underpriced as demanded by investors and do not address the issues of contentment of underpricing by issuers and underwriters. Some researchers have attempted to use asymmetric information argument to explain the relationship between issuers and underwriters in the underpricing but the data do not support the arguments. The most cited arguments, however, in depicting the relationship between issuers and underwriters are the ones that based on the conflict of interest between underwriters and issuers.

Loughran and Ritter (2002) argue that if underwriters are given an authority by issuers to conduct share allocations, this discretion is not automatically be used in the best interests of issuers. Underwriters might intentionally underprice new issues and allocate these underpriced shares to their favored clients. In return, these favored clients will have businesses with underwriters and pay fees far in excess of the competitive rates.

Using the prospect theory of Kahneman and Tversky (1979), Loughran and Ritter (2002) contend that issuing firms were more tolerant of underpricing if they simultaneously learn that the offer price is higher than they originally expected. In short, the greater the increase in entrepreneurs' wealth, the less aggressive the entrepreneurs in bargaining and negotiating over the offer price with underwriters.

\section{IPO Initial Returns and IPO Volumes}

One may characterize a market in several ways. For the IPO market, Ibbotson and Jaffe (1975) and Ritter (1984) characterize it as Hot and Cold. Using US IPO monthly data, they find that the IPO market follows a cycle with dramatic swings in the volume of new issues and the magnitude of the 
initial returns. The hot market IPOs occur when in a particular period, the new issues offerings are in high volume and resulted in severe underpricing. One the other hand, the volume of new issues and the extent of the initial returns are low during the cold market IPOs. Using US IPO monthly data for the period between 1960 and 2000, Lowry and Schwert (2002) find high IPO initial returns in one month is followed by high IPO volume in the next month. They argued that more companies file to go public after learning that favorable information has lead higher initial returns for current offerings.

Chemmanur and Fulgieri (1999), Stoughton, Wong and Zechner (2001), and Maksimovic and Pichler (2001) devised models, based on the information asymmetric and costly information gathering arguments, to explain the existence of hot and cold market IPOs. They argue that, in general, Hot Markets occur when several firms from particular industries discover new technology that lead toward increases in productivity. This favorable information is learnt by investors as those firms go public and triggers lower information asymmetry and less cost gathering. As a result, other firms in the same industry follow suit in going public. Thus, Hot Markets are the ones that have a large number of offerings by highly profitable firms from particular industries with greater investment plan than in Cold Markets.

Lowry (2003) indicates that aggregate IPO volume was a function of both changes in firms' demands for capital and changes in the level of investor optimism. Helwege and Liang (2004), however, find no evidence that firms in the Hot Markets are the ones that experience more technological innovations that resulted in increase in the demand for capital by these higher quality firms.

Helwege and Liang (2004) instead argued that aggregate IPO volume is determined largely by shifts in the demand for new shares by investors. This Investor Sentiment Hypothesis posits that increase in the level of investor optimism causes the market paying more for firms than they deserve. Thus, a large number of firms find it optimal to go public during period of high sentiment and consequently those periods become hot periods for IPOs. In other words, the IPO market is inefficient such that during periods of high sentiment, investors may overvalue firms, inducing firms to enter that market at the same time so that IPO volume is high, while during periods of low sentiment, investors may undervalue firms, causing firms to delay the market entry so that IPO volume is low. In addition, Chemmanur and Jie (2011) even construct a model that firms going public in the hot market have lower productivity and profitability than that of in the cold market.

\section{METHOD}

The sample in this study consists of all initial public offerings conducted by Indonesian firms at the Indonesia Stock Exchange (IDX) over a 5-year period between 2001 and 2005. A list of firms in this study is obtained from the IDX Annual Statistics. This publication allows having 78 IPOs. Prospectuses of these 78 IPOs are obtained from the IDX Financial Database and daily stock prices are obtained from the IDX Detailed Transaction History. The data needed for this study are as follows: (1) listing date, the offer price and the first day closing price of each IPO, (2) the length of the period from its establishment as a going concern to its IPO year, (3) the latest amount, in Indonesian Rupiahs (IDR), of total assets prior to its IPO, (4) the industry at which the firms in the sample operate. The Indonesia Stock Exchange classifies each firm into 9 industry groups and it further classifies each firm into 40 industries. The complete list of those IPO firms and their industry group across the sample period can be seen on Table 1 below: 
Table 1 IPO firms and Industry Groups in 2001-2005 Periods

\begin{tabular}{lcccccc}
\hline Industry Groups & 2001 & 2002 & 2003 & 2004 & 2005 & Total \\
\hline Basic Industry and Chemicals & 5 & 2 & - & 1 & - & 8 \\
Miscellaneous Industry & 2 & 1 & - & 1 & 1 & 5 \\
Consumer Goods Industry & 3 & 2 & 1 & - & - & 6 \\
Property, Real Estate, and Building & 3 & - & - & 1 & 4 \\
Infrastructure, Utilities, and Transportation & 1 & - & 1 & 1 & 2 & 5 \\
Finance & 4 & 8 & 3 & 3 & 4 & 22 \\
Mining & 1 & 2 & 1 & 1 & - & 5 \\
Agriculture & - & 1 & - & 1 & - & 2 \\
Trade, Service, and Investment & 11 & 6 & - & 3 & 1 & 21 \\
Total & 30 & 22 & 6 & 12 & 8 & 78 \\
\hline
\end{tabular}

Table 1 shows that during the period of 2001-2005, the IPOs in Indonesia were mostly offered by firms from two Industry Groups; Finance and Trade, Service and Investment. The IPOs from these two Industry Groups count for more than 55\% (43 of 78 IPOs) of the total IPOs during the period. The least number of IPOs comes from the Agriculture Industry Group, which are 2 of 78 IPOs.

It also can be seen in Table 1 that it is more than 65\% (52 of 78 IPOs) of the total IPOs were conducted in the year of 2001 and 2002. In the year of 2003 and 2005, however, there are only 6 and 8 IPOs occurred, respectively. The Jakarta Stock Exchange is a small stock market. On average, there was around 1 IPO in each month during the sample period. In contrast, the US market between 1960 and 2000 saw around 2 IPOs, on average, occurred in each trading day.

Table 2 Descriptive Statistics

N: 78 IPO Firms

\begin{tabular}{lllll}
\hline Variables & Mean & Min. & Max & Std. Dev. \\
\hline Firm Age (year) & 16.60 & 2 & 144 & 21.78 \\
Size (IDR 000) & $4,832,268$ & 2,001 & $250,395,000$ & $29,816,537$ \\
IPO Initial Returns (\%) & 46 & -33 & 480 & 75 \\
\hline
\end{tabular}

Firm Age is defined as the length of period from the establishment as a going concern to the IPO year. Size is the value of the total assets prior to the IPO expressed in Indonesian Rupiahs (IDR). IPO Initial Returns is the percentage difference between the offering price and the closing price of the first trading day.

Table 2 shows descriptive statistics of some variables used in this study. The average age of the sample firms is 16.60 years with the maximum and minimum ages of 144 years and 2 years, respectively. The average size (total asset value in Indonesian Rupiah-IDR) of the sample firms is around IDR 4.832 billions with the maximum and minimum sizes of IDR 250,395 billion and IDR 2 billion, respectively. There are 7 state-owned enterprises among the sample firms. A firm that has been in existence for 144 years is Perusahaan Gas Negara, a state-owned natural gas distributing firm. Based on longevity, three of the four oldest firms are state-owned enterprises. Similarly, a firm that has the maximum size is Bank Mandiri, a state-owned banking firm. Again, based on size, three of the four largest firms are state-owned enterprises.

Numerous studies have reported the underpricing of new issues that result in large average initial returns, the average price changes ratio measured from the offering price to the closing price at the end of the first day, in every nation across the globe. Table 2 also shows the existence of underpricing phenomenon at the IDX from the period of 2001 to 2005. The average initial return of these 78 IPOs is $46 \%$. The highest initial return is $480 \%$ occurred in the year 2001 when Ryane 
Adibusana, a garment firm, went public. The lowest initial return is -33\% occurred in the year 2002 when Kresna Graha Sekurindo, a financial security firm that included underwriting as its one of its businesses, went public. As mentioned earlier, the year 2001 and 2001 were the years with the heaviest IPO volumes. It is more than $65 \%$ of the total IPOs in the sample were conducted during those years.

\section{RESULTS AND DISCUSSION}

\section{Univariate Analysis}

Figure 1 presents the initial returns of every IPO in this study. It shows that initial returns are quite varied across the sample firms and periods. The initial returns are relatively higher for IPOs in 2001 and 2002. In contrast, the initial returns are relatively lower for IPOs in 2003, 2004, and 2005.

It can also be seen in Figure 1 that the initial returns of these two sub-periods have been set apart even from their first IPOs. The first IPOs in year 2001 and 2002 consistently have higher initial returns than in 2003, 2004 and 2005. Notice also in Figure 1 that the IPO volumes across the periods are varied. The IPO volume in 2001, 2002, 2003, 2004 and 2005 are 30, 22, 6, 12 and 8 IPOs respectively.

The relationship between IPO Initial Returns and Volumes can be clearly demonstrated in Figure 2. It shows that the relationship between these two variables is monotonically positive throughout the sample period such that the highest volume is paired with the highest returns, the second highest volume coincides with the second highest returns, and so on.

The positive monotonic relationship between the Initial Returns and the IPO Volumes in this study confirms the findings of Ibbotson and Jaffe (1975) and Ritter (1984) that the IPO market can be characterized by Hot and Cold Markets. The Hot (Cold) market IPOs occur when in a particular period the new issues offerings are in high (low) volume and resulted in severe (less) underpricing. In the spirit of this IPO market characterization; this study defines the year of 2001 and 2002 as the Hot Market, while the years of 2003, 2004 and 2005 are labeled as the Cold Market.

Table 3 presents the results of Kolmogorov-Smirnov test to gauge the normality assumptions of the IPO Initial Returns in this study. It can be seen that the test significantly rejects the Null Hypothesis that the IPO Initial Returns are normally distributed. The result of the test suggests one cannot put faith on parametric tests on the data used in this study. For the sake of completeness, however, the results of parametric tests are reported a long side with its non-parametric counterparts.

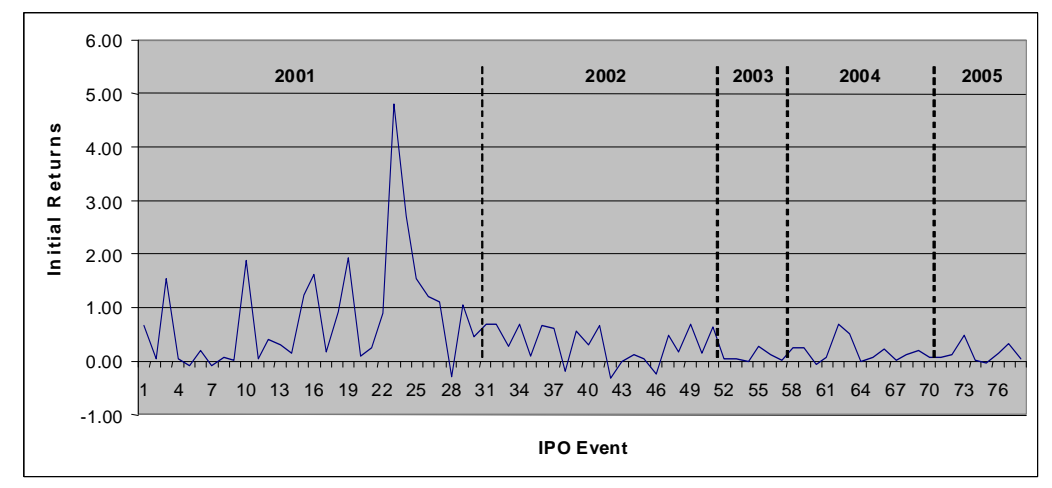

Initial Returns is the price changes ratio measured from the offering price to the closing price at the end of the first day of each IPO in the sample period.

Figure 1 Initial Returns of each 78 IPOs in the sample 
Table 4 shows the mean and median of the IPO Initial Returns during the Hot and Cold Markets. It can be seen that both mean and median of the IPO Initial Returns during the Hot and Cold Markets are positive, an indication that regardless of the IPO market characterization, IPO underpricing exists at the IDX. More importantly, the results of the tests on the differences in the Initial Returns in both markets support the notion the Initial Returns during the Hot Markets are higher than the Cold Markets. The Null Hypothesis that the observed IPO Initial Returns in Hot Markets have no difference than in Cold Markets are rejected at the one percent level by the 2-independent sample $t$ test and its non-parametric counterpart, the Mann Whitney $U$ test.

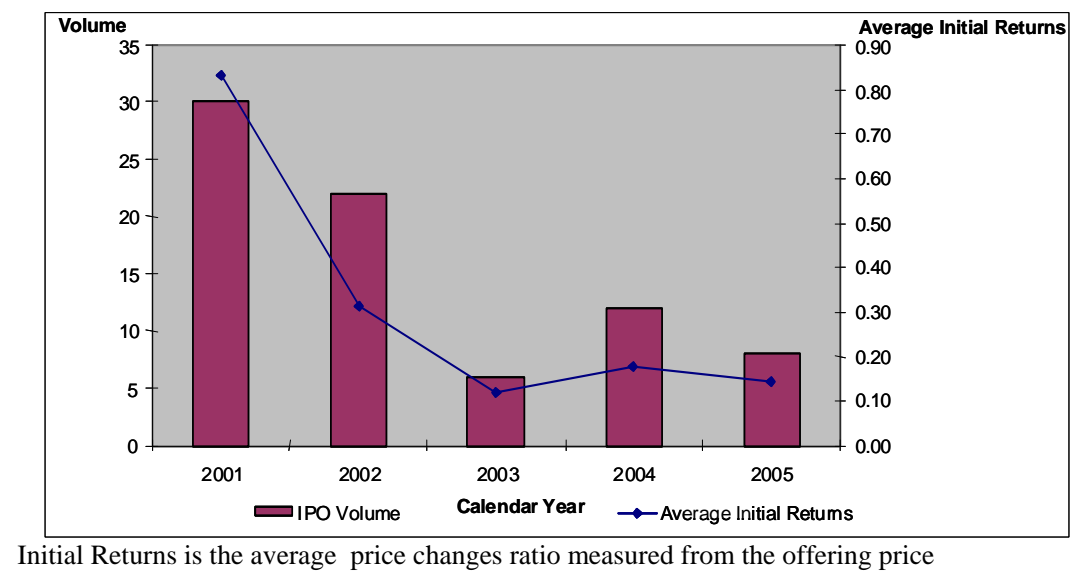

to the closing price at the end of the first day of all IPOs in each calendar year in the sample period

Figure 2 Average Initial Returns and IPO Volume

As mentioned earlier, the IDX is a small stock market. On average, there is only around 1 IPO occurs in each month. To analyze the effect of the months of the year to the IPO Initial Returns, this study grouped the IPOs based on which month of the year they occur. Figure 3 shows the Initial Returns of IPOs as grouped into particular calendar months of their occurrence. It can be seen that the busiest month during 2001-2005 is July (18 IPOs) followed by November (11 IPOs). In contrast, the quietest month during the period is February (0 IPO) followed by August (1 IPO). Inspection of the graph reveals the Last Quarter of the year (October-November) exhibit the highest average initial returns than the First Three Quarters.

Table 3 Results of Goodness of Fit Tests

\begin{tabular}{lcc}
\multicolumn{2}{c}{$\begin{array}{c}\text { Kolmogorov-Smirnov } \\
\text { Statistics }\end{array}$} & p-value \\
\hline IPO Initial Returns & 1.83 & 0.00 \\
Monthly Average IPO Initial Returns & 1.06 & 0.21 \\
\hline $\begin{array}{l}\text { Initial Returns are calculated as the difference between the offer price and the first day closing price } \\
\text { for each IPO. Monthly Average Initial Returns are the average initial returns } \\
\text { of all IPOs occurred during the calendar months of the sample period. }\end{array}$
\end{tabular}

Table 3 earlier also presents the results of Kolmogorov-Smirnov test to gauge the normality assumptions of the Monthly Average IPO Initial Returns in this study. It can be seen that the test cannot reject the Null Hypothesis that the Monthly Average IPO Initial Returns are normally distributed. The results of the tests suggest one should use parametric tests on the data used in this study. For comparison, however, the results of non-parametric tests are also reported in this study. 
Table 4 Tests for Differences in Initial Returns Hot Market (HM) and Cold Market (CM)

$$
\left(\mathrm{N}_{\mathrm{HM}}=52, \mathrm{~N}_{\mathrm{LM}}=26\right)
$$

Initial Returns

\begin{tabular}{lcc} 
& Hot Market & Cold Market \\
\hline Mean & 0.61 & 0.15 \\
Median & 0.35 & 0.18 \\
Standard Deviation & 0.87 & 0.09 \\
2-independent sample $t$-statistics & 2.67 \\
$(1$ tailed p-value $)$ & $(0.01)$ \\
Mann-Whitney $U$ statistics & 417.50 \\
$(1$ tailed p-value) & $(0.01)$ \\
Initial Returns are calculated as the difference between the offering price and the first day \\
closing price for each IPO. Hot market (HM) is defined as the year of 2001 and 2002, while \\
Cold Market (CM) is defined as the year of 2003, 2004 and 2005.
\end{tabular}

Recall that the result of the Kolmogorov-Smirnov test earlier is that one cannot reject that the Monthly Average IPO Initial Returns are normally distributed. In this part, therefore, the $t$-test is more reliable in detecting differences in the Monthly Average Initial Returns. The t-test in this instance confirms that the Monthly Average Initial Returns during the First Three Quarter are significantly less than the Last Quarter.

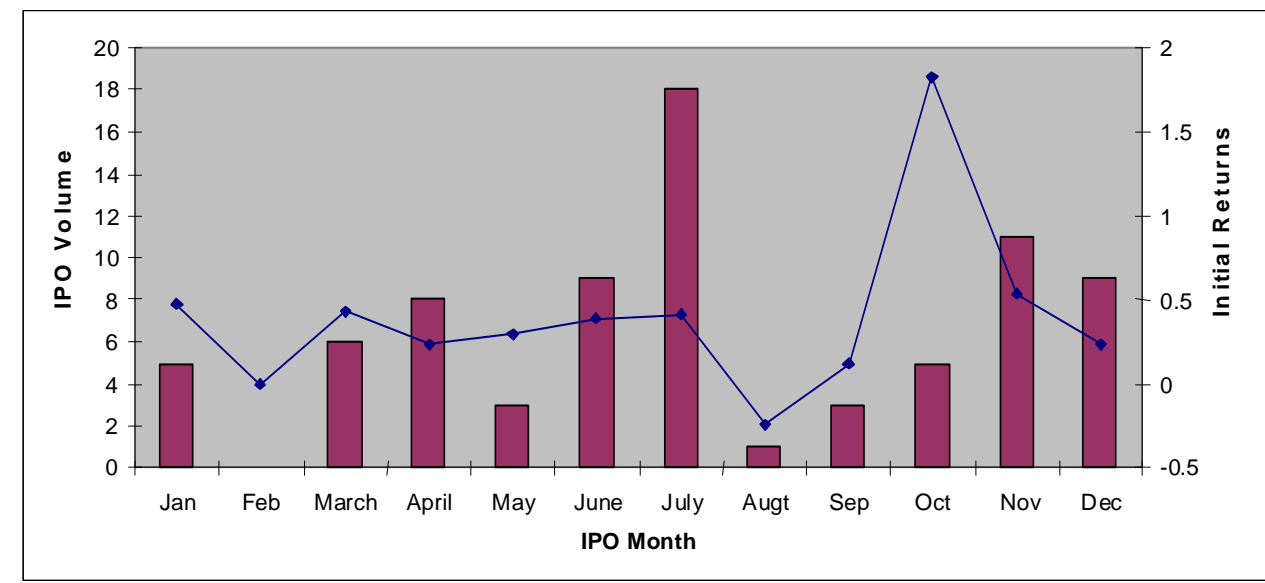

Monthly Average Initial Returns is the average price changes ratio measured from the offering price to the closing price at the end of the first day of all IPOs in each calendar month during the sample period

Figure 3 Monthly Cumulative Average IPO Initial Returns and IPO Month

Table 5 contains the results of the last univariate tests in this study. The 2-independent sample $t$-test significantly rejects the Null Hypothesis at the 5\% level that the Monthly Average Initial Returns during the First Three Quarter are equal or higher than the Last Quarter. The non-parametric test, however, only results in weakly rejection at the $10 \%$ significance level. 
Table 5 Tests for Differences in Initial Returns

The First Three Quarters (FTQ) and The Last Quarter(LQ)

$$
\left(\mathrm{N}_{\mathrm{FTQ}}=53, \mathrm{~N}_{\mathrm{LQ}}=25\right)
$$

\begin{tabular}{lcc} 
& $\begin{array}{c}\text { Cumulative Average Initial Returns } \\
\text { The First Three } \\
\text { Quarters }\end{array}$ & The Last Quarter \\
\hline Mean & 0.35 & 0.66 \\
Median & 0.17 & 0.24 \\
Standard Deviation & 0.51 & 1.05 \\
2-independent sample $t$-statistics & 2.18 \\
$\begin{array}{l}\text { (1 tailed p-value) } \\
\text { Mann-Whitney } U \text { statistics }\end{array}$ & $(0.03)$ \\
$\begin{array}{l}\text { (1 tailed p-value) } \\
\text { Initial Returns are calculated as the difference between the offer price and the first day closing } \\
\text { price for each IPO. These initial }\end{array}$ \\
corresponding IPO taken place.
\end{tabular}

\section{Multivariate Analysis}

The $t$-test and the Mann-Whitney $U$ tests are univariate tests that have a shortcoming of their inability to control other factors that may have important influences on the tests outcome. To control for other factors while testing a particular factor, therefore, a multiple regression analysis is utilized as follows:

$$
\mathrm{IR}_{\mathrm{i}}=\beta_{0}+\beta_{1} \text { Volume }_{\mathrm{i}}+\beta_{2} \text { Quarter }_{\mathrm{i}}+\beta_{5} \text { Market }_{\mathrm{i}}+\beta_{3} \text { Size }_{\mathrm{i}}+\beta_{4} \text { Age }_{\mathrm{i}}+\varepsilon_{\mathrm{i}}
$$

Where:

$\mathrm{IR}_{\mathrm{i}} \quad=$ Initial returns of IPO stock $\mathrm{i}$, which is the difference between day 1closing price and offering price

Volume $_{\mathrm{i}}=$ A dummy variable that takes the value 1 if the IPO year is 2001 or 2002, and zero otherwise

Quarter $_{\mathrm{i}}=\mathrm{A}$ dummy variable that takes the value 1 if the IPO i taken place in Quarter 4, and zero otherwise

Market $_{\mathrm{i}}=$ Returns of IDX Market Index between day -1 and day -16 of IPO $\mathrm{i}$.

Size $_{\mathrm{i}} \quad=$ Natural log of total assets of IPO Firm i, one year before going public.

Age $_{\mathrm{i}} \quad=$ Natural Log of IPO firm i's Age.

$\varepsilon_{\mathrm{i}} \quad=$ An error term.

The equation above states that that there are five factors that may explain the variance in the IPO Initial Returns of this study. The first three factors are a dummy variable (Volume) that represents the Hot and Cold Markets, a dummy variable (Quarter) that represents the market timing of an IPO, such that whether or not an IPO is conducted in the last quarter of each calendar year, and finally the market returns of the last 15 days (Market) of each IPO in the sample. The last two factors are the natural logs of total assets and firm age that represent Size and Age of IPO firms respectively. In general, the first three factors describe the market conditions when each IPO in this study is being carried out. The last two factors, Size and Age, represent the characteristic of IPO firms that may influence the perceived risks of new issues individually. Table 6 presents the estimation results for the multiple regression analysis. 
Table 6 Results of the Multiple Regression Analysis

\begin{tabular}{l}
$\mathrm{N}=$ 78 IPO FIRMS \\
$\begin{array}{l}\text { Independent } \\
\text { Variables }\end{array}$ \\
\hline Constant
\end{tabular} Coefficients
Volume

Table 6 shows the F-test which confirms the notion that at least one of the independent variables has an effect on the dependent variable. The rejection of the Null is significant at a $1 \%$ level. The $R$-squared, on the other hand, is just $18.19 \%$ and it is quite low even for cross sectional analysis. When the sample size and the number of independent variables are taken into considerations, the explanatory power of the independent variables is dropped to $12.51 \%$. Judging from the magnitudes of the adjusted $R$-squared, there is plenty of variance in the dependent variable that is unexplainable by the independent variables in the model.

Table 6 shows that Volume has the expected sign and significant at less than a $1 \%$ level. The magnitude of the coefficient is relatively big such that the difference in the IPO Initial Returns between Hot and Cold Markets is as large as 36.8\%. This study confirms the findings of Ibbotson and Jaffe (1975) and Ritter (1984) that the hot (cold) IPO markets always coincide with severe (less) underpricing. The same thing also happens to Quarter as it has the expected sign and significant at less than a 5\% level. The magnitude of the coefficient is even slightly bigger than Volume, such that the difference in the IPO Initial Returns occur in the Last Quarter of a calendar year is $38 \%$ higher than in the First Three Quarters. The finding that later issuer provide higher initial returns (lower quality IPO firms) are in contrast with the one in Çolak and Günay (2011) that the later issuers in an IPO cycle are the best firms and the first issuers are of lower quality. They argue that the best firms wait to learn the situations in the IPO market before going public.

The current literature in IPO has a tendency to explain separately between IPO Initial Returns and Volume. However, since these two IPO phenomena always occur side by side, any hypothesis advanced should be able to explain both IPO Initial Returns and Volume at the same time. So far Lowry (2003) and Helwege and Liang (2004) have found that it is the shift in level of investor optimism that cause the changes in IPO Volume. The Hot Market is caused by investors increase their demand in IPO stocks. This increased demand might cause plenty of firms to go public in the same time. A wild bullishness rallies first day closing prices. The level of offering prices during the Hot Market, on the other hand, may need to be explained further. 
Based on the reasoning of the Investor Sentiment Hypothesis, the level of offering price in the Hot Market is at least as high as in the Cold Market. Issuing firms might take advantage of the increased demand by setting higher offering prices. Investment bankers may not have any objection to these increased offering prices as long as they are accommodated by the increase in demand of new issues by investors.

There is a possibility, however, that the levels of offering prices are higher in the Hot Market than in the Cold Market. This possibility can best be explained by using the Monopsony Power hypothesis or information spillovers across IPOs as advanced by Ritter (1984) or Alti (2005) respectively. IDX is a small equity market and Indonesia is a small economy. Almost all of listed firms have headquarters in the capital city of Jakarta and, more importantly, all investment bankers reside in Jakarta.

In a small community, news travel fast. The investment banker community has a very good idea about the number of firms that will go public in the following period. Armed with this information, investment bankers would drive hard bargain to lower offering prices. In this line of explanation, investment bankers are assumed to be on the side of institutional investors because they conduct businesses with institutional investors on regular basis while IPO might be viewed as a one time deal. Therefore, in the Hot Market, first day closing prices are higher due to a wild bullishness of investors and offering prices are lower due to a high bargaining power of investment bankers.

The Monopsony Power Hypothesis can also be extended to explain the findings in this study that the IPO Initial Returns occur in the Last Quarter of a calendar year are higher than in the First Three Quarters. As a year closes to end, institutional investors conduct window dressing on their portfolios to show that the portfolios have done well under their management. This necessity would be translated into demand for further lowering offering price and communicated to investment bankers during road shows of IPOs. In turn, underwriters press issuing firm harder to get lower offering prices. Therefore, regardless it is Hot or Cold Market, the year-end IPO Initial Returns, on average, are higher than in the other parts of calendar year.

Table 6 earlier also shows the result of the tests on Market, Size and Age. Market is used to represent the latest condition on the market before issuing firms and investment bankers set offering prices. It is found to be insignificant at conventional levels. Daniel (2002) has raised doubt in the sensitivity of an offering price to the latest movement in the market. The finding of this study that Market is not statistically significant confirms his expectation.

Size and Age, on the other hand, represent risks of issuing firms. These two variables may be used by investors to solve information asymmetric problem surrounding the offerings. Of these two variables, only Size is found to have expected sign and be weakly significant at a $10 \%$ level. Investors perceive larger firms, as compared to smaller firms, present fewer risks because they possess more ways and means to flourish in the market place. Therefore, the larger the size of IPO firm, the less is the underpricing.

\section{CONCLUSION}

This study is an attempt to investigate factors that correlate with the IPO Initial Returns at the Jakarta Stock Exchange. Those factors are IPO Volume, Quarter, Lag Market Returns, Size and Age. The first three factors describe the market conditions when each IPO in this study is being carried out. The last two factors, Size and Age, represent the characteristic of IPO firms that may influence the perceived risks of new issues individually. Of these 5 factors, it is found that only Volume, Quarter and Size to have the expected signs and statistically significant at conventional levels. 
Judging from the magnitudes of the coefficients, IPO Volume and Quarter in which an IPO taken place are the most notable. They are .368 and .38 respectively, which means the difference in IPO Initial Returns between Hot and Cold Markets (the Last Quarter and the First Three Quarters) while keeping the other factors constant is 36.8\% (38\%). The Investment Sentiment Hypothesis has been found to explain the existence of Hot and Cold Markets, which is the increase in the first day closing prices and in the offering prices (Lowry, 2003; Helwege and Liang, 2004). As long as the increase in the first day closing prices is higher than in the offering prices, there will be spikes in IPO Initial Returns during Hot Markets.

This study also discusses the possibility that during Hot Markets, the first day closing prices increase while the offering prices decrease. The Monopsony Power Hypothesis as advanced by Ritter (1984) and Alti (2005) offers an alternative venue in explaining the possibility such that in a small stock market like the Indonesia Stock Exchange, investment bankers have full information regarding the number of firms to go public in the next period. This information is used by investment bankers to demand issuing firms for lower offering prices on behalf of their influential investors. Further studies should be directed to reveal the characteristics of the components that made up IPO Initial Returns during Hot and Cold Markets and across periods. Finding their characteristic will enrich the literature in the field.

\section{REFERENCES}

Alti, A., (2005). IPO market timing. Review of Financial Studies, 18(3), 1105-1138.

Benveniste, L. M. and Spindt, P. A. (1989). How investment bankers determine the offer price and allocation of new issues. Journal of Financial Economics, 24(2), 343-361.

Butler, A. W., Keefe, M. O., and Kieschnick, R. (2014). Robust determinants of IPO underpricing and their implications for IPO research. Journal of Corporate Finance, 27, 367-383

Chemmanur, T. and Fulghieri, P. (1999). A theory of the going-public decision. Review of Financial Studies, 12, 249-279.

Chemmanur, T. and He, Jie. (2011). IPO waves, product market competition, and the going public decision: Theory and evidence. Journal of Financial Economics, 101, 382-412.

Daniel, K. (2002). Discussion on why don't issuers get upset about leaving money on the table. Review of Financial Studies, 15, 445-454.

Helwege, J. and Liang, N. (2004). Initial public offerings in hot and cold markets. Journal of Financial and Quantitative Analysis, 39, 541-560.

Ibbotson, R. G. (1975). Price performance of common stock new issues. Journal of Financial Economics, 2, 235-272.

Ibbotson, R. G. and Jaffe, J. F. (1975). Hot issue markets. Journal of Finance, 30, 1027-1042.

Kahneman, D. and Tversky, A. (1979). Prospect theory: An analysis of decision under risk. Econometrica, 47(2), 263-291.

Loughran, T., and Ritter, J. (2002). Why don't issuers get upset about leaving money on the table. Review of Financial Studies, 15(2), 413-443. 
Lowry, M., and Schwert, G.W. (2002). IPO market cycles: Bubbles or sequential learning? Journal of Finance, 57, 1171-1198.

Lowry, M. (2003). Why does IPO volume fluctuate so much? Journal of Financial Economics, 67, 340.

Maksimovic, V. and Pichler, P. (2001). Technological innovation and initial public offerings. Review of Financial Studies, 14(2), 459-494.

Reilly, F.K. and Hatfield, K. (1969). Investors experience with new stock issues. Financial Analysis Journal, 25, 73-80.

Ritter, J. (1984). The hot issue market of 1980. Journal of Business, 57, 215-240.

Rock, K. F. (1986). Why new issues are underpriced. Journal of Financial Economics, 15, 187- 212.

Stoughton, N., Wang, K. and Zechner, J. (2001). IPOs and product quality. Journal of Business, 74(3), 375-408.

Welch, I. (1992). Sequential sales, learning and cascades. Journal of Finance, 47, 695-732. 